\section{SPORTS INJURY AND REHABILITATION OF LOWER LIMB SOFT TISSUE}

\author{
LESÕES DO ESPORTEE A REABILITAÇÃO DO TECIDO MOLEDEMEMBROS INFERIORES \\ LESIONES DEL DEPORTEY LAREHABILITACIÓN DEL TEJIDO BLANDO DE MIEMBROS INFERIORES
}

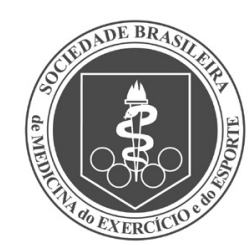

Original Article

ARtigo OrigINAL Artículo Original
Zhilin Zhu' (D)

(Physical Education Professional)

Yuanyuan $\mathrm{Ma}^{2}$ (D)

(Physician)

1. Henan Medical College, Zheng zhou ,Henan,China.

\section{Correspondence}

Zhilin Zhu

Henan, China, 450000.

zhuzhilin25@163.com

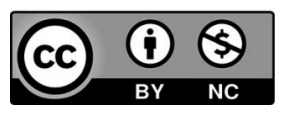

\begin{abstract}
Introduction: the assessment and proper management of lower extremity soft tissue injury is very important. Because the mechanism and clinical manifestations of lower extremity soft tissue injury are varied, it is necessary to make an accurate assessment based on the specific situation of the patient. Objective: To explore the mechanism and rehabilitation methods of lower limb soft tissue sports injury. Methods: In clinical practice, external application of Chinese herbal medicine combined with cold compresses, massage, pot dipping, hot immersion irradiation and other methods were used. Results: The self-made Chinese herbal medicine external ointment, swelling and pain relieving Chinese herbal medicine wine combined with electromagnetic wave therapy instrument is one of the commonly used and effective methods to treat sports injury of lower extremity soft tissue in health care experimental centers. It has the most remarkable effect on local burning, stasis, swelling and pain caused by the soft tissue injury of various lower limbs in various parts of the human body. Conclusions: Timely functional rehabilitation training after sports injury can promote the functional healing and rehabilitation of the body after injury, maintaining the good functional state of each organ system of the body. Level of evidence ll; Therapeutic studies - investigation of treatment results.
\end{abstract}

Keywords: Lower extremity; Athletic injuries; Rehabilitation.

\section{RESUMO}

Introdução: A avaliação e o manejo adequados de lesões do tecido mole dos membros inferiores é muito importante. Como o mecanismo e as manifestações clínicas das lesões do tecido mole dos membros inferiores são variados, é necessário fazer uma análise precisa, baseada na situação específica do paciente. Objetivo: Explorar os métodos mecânicos e de reabilitação de lesões do esporte no tecido mole de membros inferiores. Métodos: Na prática clínica, a aplicação de ervas medicinais chinesas de uso externo combinada com compressas frias, massagens, pot dipping, irradiação com imersões quentes e outros métodos foram usados. Resultados: A pomada artesanal de ervas médica de uso externo, o vinho de ervas médico chinês para o alívio de dores, combinado com a terapia de ondas eletromagnéticas é um dos métodos mais eficazes e comumente usados para tratar de lesões do esporte do tecido mole de membros inferiores em centros de saúde experimentais. Tem um efeito perceptível na queimação local, estase, inchaço e dor causados por lesões do tecido mole de vários membros inferiores em várias partes do corpo humano. Conclusões: O treinamento de reabilitação funcional adequado após lesões do esporte pode promover a recuperação e a reabilitação funcional do corpo após lesões, mantendo o estado funcional correto de cada sistema orgânico do corpo. Nível de evidência Il; estudos terapêuticos - investigação de resultados de tratamento.

Descritores: Extremidade inferior; Traumatismos em atletas; Reabilitação.

\section{RESUMEN}

Introducción: La evaluación y manejo adecuados de lesiones del tejido blando de los miembros inferiores es muy importante. Como el mecanismo y las manifestaciones clínicas de las lesiones del tejido mole de los miembros inferiores son variados, es necesario hacer un análisis preciso, basado en la situación específica del paciente. Objetivo: Explorar los métodos mecánicos y de rehabilitación de lesiones del deporte en el tejido blando de miembros inferiores. Métodos: En la práctica clínica, se utilizaron la aplicación de hierbas medicinales chinas de uso externo combinada con compresas frías, masajes, pot dipping, irradiación con inmersiones calientes y otros métodos. Resultados: La pomada artesanal de hierbas médicas de uso externo, el vino de hierbas médico chino para alivio de dolores, combinado con la terapia de ondas electromagnéticas, es uno de los métodos más eficaces y comúnmente usados para tratar lesiones del deporte en el tejido blando de miembros inferiores en centros de salud experimentales. Tiene un efecto perceptible en el ardor local, éxtasis, hinchazón y dolor causados por lesiones del tejido blando de varios miembros inferiores en varias partes del cuerpo humano. Conclusiones: El entrenamiento de rehabilitación funcional adecuado tras lesiones del deporte puede promover la recuperación y la rehabilitación funcional del cuerpo tras lesiones, manteniendo el estado funcional correcto de cada sistema orgánico del cuerpo. Nivel de evidencia ll; Estudios terapéuticos - investigación de resultados de tratamiento.

Descriptores: Extremidade inferior; Traumatismos em atletas; Reabilitação. 


\section{INTRODUCTION}

The treatment of soft tissue injury of lower extremity is an important part of orthopedics. With the development of social economy, the incidence of soft tissue injury of lower extremity caused by road traffic injury, work-related injury and other high-energy violence is increasing year by year. If treated improperly, it can lead to serious complications such as soft tissue defect, bone exposure, osteomyelitis, fracture nonunion, limb necrosis and so on, which has a high disability rate and may even endanger life. Lower extremity soft tissue Injury should first be assessed according to the severity of Injury (ISS) or Advanced Trauma Life Support (ATLS) scoring system to determine whether there are multiple life-threatening injuries. If there should be to save the first life.'

Some studies have shown that when ISS $<16$ points, ultimate treatment of fracture or long-term surgery can be performed directly. However, for ISS $>25$ points, especially when combined with chest trauma (AIS $>2$ points), only simple debridement and temporary fixation should be performed in the early stage. ${ }^{2}$ With the continuous improvement of orthopedic diagnosis and treatment techniques and concepts, limb salvage can now be performed for some injuries that previously required amputation. Therefore, in the actual treatment, the specific injury, social and economic benefits and existing technical conditions of each patient should be taken into consideration, rather than relying solely on a scoring system. ${ }^{3}$

\section{METHOD}

\section{Questionnaire survey}

Questionnaire survey on sports injury was carried out among the students who went to the sports health experiment center. A total of 145 questionnaires were sent out, and 145 were effectively received, with a recovery rate of $100 \%$. The effective questionnaire was collected and analyzed. All the data obtained were classified and tested and counted by CASIOFX-4500P calculator to meet the research needs. ${ }^{4}$

\section{Clinical data of injured patients}

Among the 145 patients, 105 were male, accounting for $72.41 \%$; 40 cases were female, accounting for 27.59\%; They are between 18 and 23 years old. The longest treatment time was $3 \mathrm{~h}$, the shortest was $20 \mathrm{~min}$, and the average time was 1.5h. There were 96 cases of acute soft tissue injury of lower limbs, accounting for $66.21 \%$ of the injured patients, and 49 cases of chronic soft tissue injury, accounting for $33.79 \%$ of the injured patients. Patients with acute injuries were more in lower grades than those in higher grades, and patients with chronic injuries were more in higher grades than those in lower grades. ${ }^{5}$ (Table 1)

\section{Time, type and location of injury}

From the analysis of students' sports time injury, 94 cases were injured in after-class exercises, accounting for $64.83 \%$, which was related to the students' self-training, competition and high sports intensity in extracurricular activities. The number of injured in class was less 51 cases, accounting for $35.17 \%$, which was closely related to teachers' reasonable organization of teaching. In extracurricular sports activities,

Table 1. Proportion of male, female, acute and chronic patients in 145 cases.

\begin{tabular}{c|c|c}
\hline Gender & Number & The proportion \\
\hline Man & 105 & $72.41 \%$ \\
\hline Woman & 40 & $27.59 \%$ \\
\hline Lower extremity soft tissue acute & 96 & $66.21 \%$ \\
\hline $\begin{array}{c}\text { The lower extremity soft } \\
\text { tissue is chronic }\end{array}$ & 49 & $33.79 \%$ \\
\hline
\end{tabular}

students should take care of each other and observe sports medical supervision, which can reduce the probability of injury. Sports injury type in the front is: sprain, bruise, strain, followed by collision injury, contusion. Sports injury site in front of the lower limbs, trunk, upper limbs, head and neck parts. ${ }^{6}$

\section{RESULTS}

1. Cold and hot compress therapy

Cold compress therapy: apply to inchoate local soft tissue injury patient. After injury, the affected area should be cold compress in time, which can make capillary constriction, reduce local congestion, reduce the sensitivity of nerve endings and relieve pain, prevent inflammation, and diverge the heat conduction in the body. Cold compress method can be soaked with a small towel in cold or ice water, twisted into a semi-dry compress on local, every $1 \sim 3$ min replacement, lasting $15 \sim$ $20 \mathrm{~min}$. Also can use ice bags, ice into plastic bags wrapped in a towel to apply to local. In the not too cold season, the injured limb can also be soaked in cold water, or washed with tap water. When washing, the amount of water, flow rate and time should be properly controlled. The skin abrasions and breakages at the wound should be used with caution, so as not to deepen the condition. However, some people are not very useful with this method. (Figure 1), ${ }^{7,8}$

2. Chinese massage therapy

- Press method: press method is a kind of technique with strong stimulation, suitable for all parts of the body, can relieve spasmolysis, meridians and activating collolitions, pain relief, plastic restoration. It has the function of relaxing muscle and eliminating fatigue.

- Push rub method: push rub method is a soft warm stimulation, with warm meridians, qi and blood circulation, detumescence and analgesic effect, often used in deficiency cold syndrome, can improve the local skin and tissue temperature, enhance the body cold resistance ability. Push rubbing method can be used at the beginning and end of massage, or between manipulations, to ease the pain or discomfort.

- Kneading method: kneading method combined with the method can go deep into the deep muscle, relieve spasm, soften scar, release adhesions. Rubbing method can promote blood circulation, improve the metabolism of local tissues, and regulate qi, promote blood circulation and dissipate blood stasis, relieve tension and strong manipulative stimulation caused by pain and discomfort.

- Extrusion and extension method: Extrusion and extension is to widen the joint space, adjust the soft tissue of the muscles and ligaments, straighten out the muscles and bones, release the adhesion and smooth the joints. This method is applicable to a wide range of people. ${ }^{9}$ (Figure 2) 3. Cupping therapy

- The principle of acupoint selection: the same as the massage therapy acupoint selection technique, the injury location is desirable nearby acupoints, such as sciatica to take Huantiao point, Weizhong point, muscle strain is the acupoint;

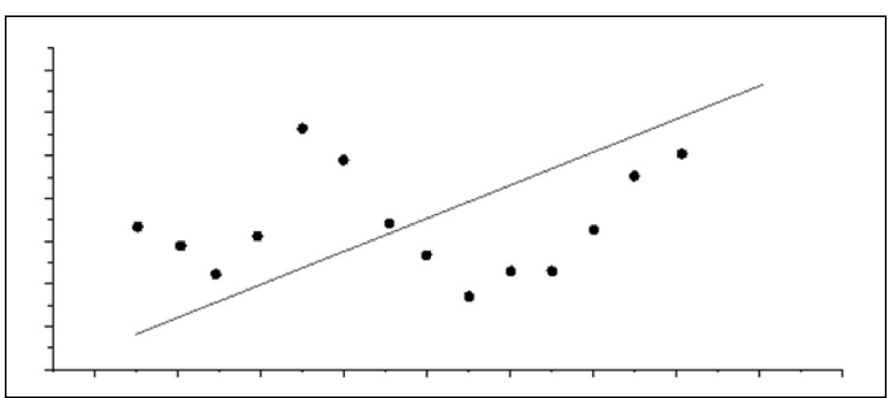

Figure 1. Effectiveness of cold and hot compress therapy on patients with soft tissue injury. 
- Pot selection: cupping, drainage can, walk can, shaking can, pricking can, in which the cupping method can be used paper or $95 \%$ alcohol cotton ball lit into the pot, the mouth of the pot quickly buckled in the treatment site, or tweezers with lit alcohol ball or paper, into the tank rotating combustion for a while, quickly take out the mouth of the tank buckle in the treatment site;

- Tank retention time: according to the strength of the tank suction, suction can be pulled for $3 \sim 5 \mathrm{~min}$, weak suction can be pulled for 10 $\sim 20 \mathrm{~min}$; Hot weather to stay the tank time is shortened, cold slightly extended, generally every other day cupping once, $5 \sim 7$ times for a course of treatment;

- How to take the pot: when taking the pot, one hand presses the skin on the edge of the mouth of the pot, and the other hand moves the cupping pot diagonally so that the air enters the pot. Do not force the cupping to avoid damaging the skin, the pot after the skin redness is a normal reaction, such as the occurrence of blisters with disinfection puncture, painted purple liquid. This approach does not work for most people. (Figure 3)

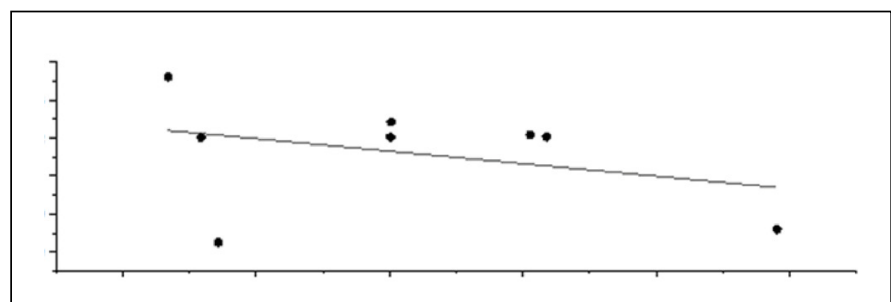

Figure 2. The effectiveness of traditional Chinese massage therapy on people with soft tissue injury.

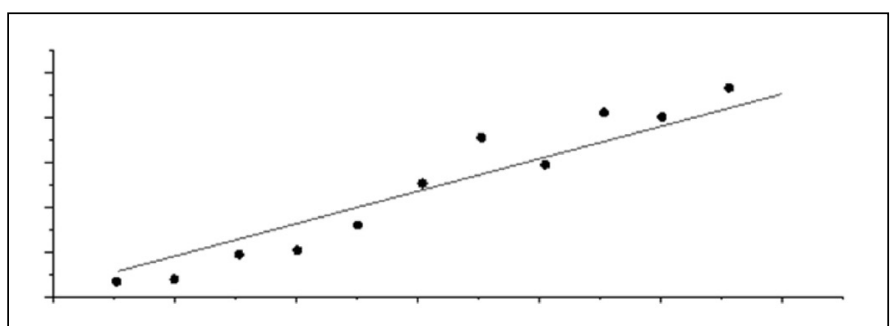

Figure 3. Effectiveness of cupping therapy in patients with soft tissue injury.

\section{DISCUSSION}

As shown in Figure 1-3, separate methods are not suitable for all groups of people, so the rehabilitation of sports injuries must be combined with traditional Chinese medicine therapy and comprehensive therapy. Traditional Chinese medicine treatment works in local depths, reaching ligaments, nerves and joint tissues. It can cause regular and irregular muscle contractions and massage, relieve pain, accelerate local tissue metabolism, improve blood circulation, relax muscles and relax meridians through nerve stimulation. 10,11 Promote the absorption of inflammatory exudate and the elimination of pain-causing substances, eliminate local muscle spasm and soft tissue swelling on nerve tissue stimulation and compression symptoms, promote tissue repair. The time it takes to heal from an ankle injury is influenced by many factors, including age, general fitness prior to injury, severity of injury and whether or not an injury has occurred. If the injury does not pay attention to treatment, especially minor injuries, easy to prolong the course of repeated injury and easy to relapse. Therefore, regardless of the severity of the injury, it is necessary to develop a thorough rehabilitation plan, timely and timely targeted treatment, to ensure the recovery of the best function before the injury. Therefore, no matter the degree of injury, the standardization of treatment is very important, and the computer intermediate frequency can be used as an important means of rehabilitation treatment of various sports injuries. Computer medium frequency therapy can replace acupuncture and massage, and has the function of hyperthermia, especially for chronic injury arthritis, and can achieve a good therapeutic effect on the treatment of acute soft tissue and joint injury, playing the role of complete functional recovery.12

\section{CONCLUSION}

This paper puts forward a method of combining traditional Chinese medicine therapy with comprehensive therapy for rehabilitation of sports injury. The specific content of this method in clinical practice is mainly through external application of Chinese herbal medicine combined with cold compress, massage, pot poking, hot immersion irradiation and other methods. The results showed that the self-made Chinese herbal medicine external ointment, detumescence and analgesia Chinese herbal medicine wine combined with the electromagnetic wave therapy instrument is one of the commonly used and effective methods for the treatment of lower limb soft tissue sports injury in the health care experimental center. It has the most remarkable effect on the local burning, stasis, swelling and pain caused by the soft tissue injury of various lower limbs in various parts of the human body. At the same time, it will also play a better role in the functional rehabilitation of patients with chronic sports injury by using methods such as pulling and irrigation and physical therapy. To prove that the timely functional rehabilitation training after sports injury can promote the functional healing and rehabilitation of the body after injury, maintain the good functional state of the body organ system, and can maintain the acquired sports quality and the best sports competitive state.

All authors declare no potential conflict of interest related to this article

AUTHORS' CONTRIBUTIONS: Each author made significant individual contributions to this manuscript. Zhilin Zhu: writing and performing surgeries; Yuanyuan Ma: data analysis and performing surgeries, article review and intellectual concept of the article.

\section{REFERENCES}

1. Ahmed H, Iqbal A, Anwer S, Alghadir A. Effect of modified hold-relax stretching and static stretching on hamstring muscle flexibility. J Phys Ther Sci. 2015;27(2):535-8. doi: 10.1589/jpts.27.535

2. Duc DM, Phuoc PD, Tuy TX, et al. Study on the transient response of lower limb rehabilitation actuator using the pneumatic cylinder. Mechatronics Electrical Power and Vehicular Technology. 2018;9(2):65

3. Ji Y, Yun D, Jang H, et al. Study on efficacy of gait training for hemiplegia patients using lower-limb wearable robot. Journal of the Korean Society for Precision Engineering. 2015;32(10):879-83.

4. Akkaya S, Akkaya N, Güngör HR, Ağladıoğlu K, Ök N, Özçakar L. Sonoelastographic evaluation of the distal femoral cartilage in patients with anterior cruciate ligament reconstruction. Eklem Hastalik Cerrahisi. 2016;27(1):2-8. doi: 10.5606/ehc.2016.02

5. Zhu W, Lu W, Cui J, Peng L, Ou Y, Li H, et al. Treatment of tibia avulsion fracture of posterior cruciate ligament with high-strength suture fixation under arthroscopy. Eur J Trauma Emerg Surg. 2017;43(1):137-43. doi: 10.1007/s00068-015-0606-9

6. Ladlow $P$, Nightingale TE, Mcguigan MP. Influence of injury severity and recovery environment on physical activity and function following lower-limb amputation: 2412 Board \#1 May 28 6:00 PM - 7:00 PM. Medicine \& Science in Sports \& Exercise. 2020;52(7S):656-7.
7. Sumiko Y. Development of a Lower Limb Orthosis for Stroke Patients - Specification Based on the Gait Analysis and Resources for Clinical Usage. Journal of The Society of Instrument and Control Engineers. 2020;59(1):23-7.

8. Rafael $\mathrm{V}$, Lentini $\mathrm{CM}$, De O, et al. High intensity exercise and flexibility of the lower limbs: dose-effect study. Revista Brasileira de Medicina do Esporte. 2016;22(4):311-4

9. Gonell AC, Romero JA, Soler LM. Relationship between the y balance test scores and soft tissue injury incidence in a soccer team. Int J Sports Phys Ther. 2015;10(7):955-66. PMID: 26673848.

10. Jiang $L$, Wei $X$, Dai M. A study on effects botulinum toxin type A injection on pathological of gastrocnemius in rats with spinal cord injury. Chinese Journal of Rehabilitation Medicine. 2017;32(7):738-43.

11.Zhang G, Qin $Q$, Chen Z, et al. Quantitative study on the effects of the frontend styling of SUV on pedestrian lower limbs injury. Qiche Gongcheng/Automotive Engineering 2017;39(4):424-31.

12. Ahmed H, lqbal A, Anwer S, Alghadir A. Effect of modified hold-relax stretching and static stretching on hamstring muscle flexibility. J Phys Ther Sci. 2015;27(2):535-8. doi: 10.1589/jpts.27.535 